\title{
A Transposon Insertion in the Escherichia coli uvrC Gene; UvrC Protein is Absolutely Required for the Incision Step in Excision Repair
}

\author{
By ROBIN G. WALTERS, ${ }^{1}$ HAF O. WILBRAHAM, ${ }^{1}$ PETER STRIKE ${ }^{1 *}$ AND \\ JOHN W. FORSTER ${ }^{2}$ \\ ${ }^{1}$ Department of Genetics, Liverpool University, P.O Box 147, Liverpool L69 3BX, UK \\ ${ }^{2}$ Department of Agricultural Botany, School of Agricultural Sciences, Penglais, Aberystwyth, \\ Dyfed $S Y 23$ 3DD, UK
}

(Received 4 August 1987; revised 5 October 1987)

\begin{abstract}
The formation of single-stranded breaks in DNA following UV irradiation is assessed in uvrC34 mutants. By altering the SOS DNA-repair system, either by additional mutations or by using drugs affecting transcription or translation, it is shown that such single-stranded breaks require one or more DNA-damage-inducible functions. A UV-sensitive strain is characterized as carrying a $\mathrm{Tn} 10$ insertion into the $u v r C$ gene. The absence of post-irradiation incision in this strain demonstrates that $u v r C$ function is absolutely required in vivo for the incision stage of excision repair, and suggests that other $u v r C$ mutants are 'leaky'.
\end{abstract}

\section{INTRODUCTION}

Excision repair of UV-irradiated DNA in Escherichia coli requires the products of the uvrA, $u v r B$ and $u v r C$ genes. The products of these genes combine in vitro to form UvrABC excinuclease, which makes single-stranded cuts at two sites, one each side of the damaged region of DNA (Sancar \& Rupp, 1983). The efficiency of this process is enhanced by the presence of DNA helicase II (the $u v r D$ gene product) and DNA polymerase I. These enzymes act together to release a damage-containing fragment of single-stranded DNA, 12-13 nucleotides in length, and to resynthesize that region of DNA, allowing turnover of $U v r A, U v r B$ and $U v r C$ proteins (Husain et al., 1985; Caron et al., 1985). Studies using purified enzyme preparations have indicated that all three $u v r$ gene products are required for the initial incision process (Seeberg $e t$ al., 1976; Sancar \& Rupp, 1983).

In vivo and in vitro studies consistently show $u v r A$ and $u v r B$ mutants to be completely defective in incision (Seeberg et al., 1980); in contrast, uvrC mutants show a measurable level of UVdependent incision in vivo. Such UV-induced single-stranded breaks accumulate more slowly and to a lesser extent than in $u v r^{+}$strains. Incisions made in $u v r C$ cells are not followed by dimer excision nor by repair synthesis (Kato, 1972).

Post-irradiation incision in $u v r C$ mutants has been investigated in vitro using permeabilized cells; the results have been contradictory. In the presence of nicotinamide mononucleotide (NMN), which inhibits ligase-mediated resealing of single-stranded breaks, plasmolysed $u v r C$ cells appear as incision defective as uvrA cells (Seeberg \& Strike, 1976). However, when permeabilized by treatment with toluene, again in the presence of $N M N$, they have variously been reported as being either completely proficient (Sharma \& Moses, 1979) or completely defective (Seeberg et al., 1980) in $u v r^{+}$-dependent incision. The reasons for the discrepancies are unclear, but may involve the observed wide variation in the efficiencies of $u v r^{+}$-dependent and $u v r^{+}$-independent incision between intact, plasmolysed and toluene-treated cells.

If ligase is inactivated in intact cells by the introduction of a lig-7(Ts) mutation and preincubation at the non-permissive temperature, the initial rate (but not the final level) of postirradiation incision is increased in $u v r C$ mutants (Seeberg \& Rupp, 1975). It was originally 
suggested that UvrC protein might have a role in blocking the action of ligase on the incisions made by the $u v r A$ and $u v r B$ gene products. This hypothesis is incompatible with further studies showing that incision capacity in $u v r C$ mutants saturates at high UV doses (Seeberg et al., 1980).

Ligase inactivation leads to efficient induction of the SOS regulon (Morse \& Pauling, 1975). The increased rate of incision in a lig-7(Ts) mutant might therefore be due either to the resulting increased availability of UvrA and UvrB, or to a damage-inducible function capable of substituting for UvrC to some extent. An alternative is that those $u v r C$ mutations studied ( $u v r C 34, u v r C 56)$ are 'leaky', and permit a low level of (UvrC-dependent) aberrant incision. These hypotheses have been tested by investigating strand incision: (i) in $u v r C 34$ cells in which the SOS response has been altered by additional mutations or by treatment with drugs, and (ii) in a $u v r C:$ Tn 10 mutant.

\section{METHODS}

Bacteria and bacteriophages. All the $E$. coli and bacteriophage $\lambda$ strains, and plasmids, used are listed in Table 1 .

Media. $\mathrm{M} 9$ buffer contained (per litre of water): $\mathrm{NH}_{4} \mathrm{Cl}, 1 \mathrm{~g} ; \mathrm{KH}_{2} \mathrm{PO}_{4}, 3 \mathrm{~g} ; \mathrm{Na}_{2} \mathrm{HPO}_{4} .2 \mathrm{H}_{2} \mathrm{O}, 7.5 \mathrm{~g} ; \mathrm{NaCl}, 5 \mathrm{~g}$; $\mathrm{MgSO}_{4} .7 \mathrm{H}_{2} \mathrm{O}, 0.246 \mathrm{~g} ; \mathrm{CaCl}_{2}, 0.011 \mathrm{~g} . \mathrm{K}$ medium was $\mathrm{M} 9$ buffer supplemented with $1 \%(\mathrm{w} / \mathrm{v})$ glucose, $1 \%(\mathrm{w} / \mathrm{v})$ Casamino acids, and $0.0001 \%$ thiamin. $\mathrm{L}$ agar contained (per litre of water): Bacto-tryptone, $10 \mathrm{~g}$; yeast extract, $5 \mathrm{~g} ; \mathrm{NaCl}, 10 \mathrm{~g} ;$ agar, $15 \mathrm{~g}$.

UV survival. Fresh stationary-phase cultures of bacteria were resuspended in M9 buffer to a cell density of approximately $10^{9}$ cells $\mathrm{ml}^{-1}$. Samples $(0 \cdot 1 \mathrm{ml})$ of appropriate dilutions were spread on $\mathrm{L}$ agar plus antibiotics, and irradiated with UV light at $254 \mathrm{~nm}$. Survivors were scored after incubation at $37^{\circ} \mathrm{C}$ overnight. Each result is the mean of up to four replicates.

Growth and irradiation of ${ }^{3} \mathrm{H}$-labelled cells. Cells were grown for several generations to mid-exponential phase in $5 \mathrm{ml} \mathrm{K}$ medium supplemented with uridine $\left(50 \mu \mathrm{g} \mathrm{m}^{-1}\right)$ and $\left[{ }^{3} \mathrm{H}\right]$ thymidine $\left(5 \mu \mathrm{Ci}, 70-90 \mathrm{Ci} \mathrm{mmol}^{-1}\right)(185 \mathrm{kBq}$, 2.59-3.33 TBq mmol ${ }^{-1}$ ). After washing twice in $40 \mathrm{~mm}-\mathrm{Tris} / \mathrm{HCl}, \mathrm{pH} 8 \cdot 0$, cells were resuspended in $5 \mathrm{ml} \mathrm{M} 9$ buffer and irradiated $\left(24 \mathrm{~J} \mathrm{~m}^{-2}\right)$ on ice. $\mathrm{K}$ medium $(5 \mathrm{ml}$, containing rifampicin or chloramphenicol if necessary at $200 \mu \mathrm{g} \mathrm{ml}^{-1}$ ) was added and the cells were incubated with aeration at 37 or $42^{\circ} \mathrm{C}$ to allow strand-break formation.

Measurement of DNA strand breaks. Samples $(0 \cdot 1 \mathrm{ml})$ of irradiated cells were incubated on ice for $10 \mathrm{~min}$ with

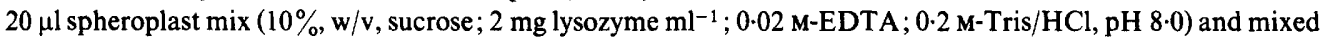
with equal volumes of lysis mix ( $1 \%$, w/v, Sarkosyl NL-97; $0.01 \mathrm{M}$-EDTA) on $5 \mathrm{ml} 5-20 \%(\mathrm{w} / \mathrm{v})$ alkaline sucrose density gradients. ${ }^{14} \mathrm{C}$-labelled T4 DNA was added as a size marker, and gradients were spun at 35000 r.p.m. for $90 \mathrm{~min}$ at $20^{\circ} \mathrm{C}$ in an SW50 rotor. Fractions $(0.25 \mathrm{ml})$ were collected onto $\mathrm{GF} / \mathrm{C}$ filters using a peristaltic pump, and washed in ice-cold $10 \%(\mathrm{w} / \mathrm{v}) \mathrm{TCA}, 0.1 \mathrm{M}-\mathrm{HCl}$, and finally ethanol. Filters were then dried and counted in a scintillation counter. Values for the number of strand breaks per $10^{8}$ atomic mass units of DNA $\left(10^{8} / \mathrm{M}_{\mathrm{n}}\right)$ were obtained as described previously (Seeberg \& Strike, 1976).

Preparation of chromosomal DNA. Samples $(200 \mathrm{ml})$ of a fresh stationary-phase culture were washed in M9 buffer and resuspended in $8.5 \mathrm{ml} 25 \%(\mathrm{w} / \mathrm{v})$ sucrose, $0.05 \mathrm{M}$-Tris $/ \mathrm{HCl}, \mathrm{pH} 8.0$. Lysozyme $\left(0.65 \mathrm{ml}\right.$ of a $10 \mathrm{mg} \mathrm{ml}^{-1}$ solution) was added, and the cells were incubated on ice for $15 \mathrm{~min}$. After addition of $3.3 \mathrm{ml} \mathrm{0.2} \mathrm{M-EDTA,} \mathrm{pH} \mathrm{7.8,}$ and a further $5 \mathrm{~min}$ on ice, the cells were lysed with $3.3 \mathrm{ml} 1 \%(\mathrm{w} / \mathrm{v})$ Brij-58, $0.4 \%$ sodium deoxycholate, $0.05 \mathrm{M}$ Tris/ $\mathrm{HCl}, \mathrm{pH} 8 \cdot 0,0.002 \mathrm{M}$-EDTA. Cellular protein was degraded by the addition of proteinase $\mathrm{K}$ to $100 \mu \mathrm{g} \mathrm{ml}-1$ and incubation overnight at $4{ }^{\circ} \mathrm{C}$. Any remaining protein was extracted by heating at $60^{\circ} \mathrm{C}$ for $10 \mathrm{~min}$, followed by several extractions with phenol/chloroform $(1: 1, \mathrm{v} / \mathrm{v})$. Nucleic acids were precipitated with $0 \cdot 1$ vol. $5 \mathrm{M}-\mathrm{NaCl}$ and 2 vols ethanol, washed in $70 \%(\mathrm{v} / \mathrm{v})$ ethanol, dried, redissolved in TE $(0.01 \mathrm{M}$-Tris/HCl, $0.001 \mathrm{M}-\mathrm{EDTA}, \mathrm{pH} 7.5)$, and treated with $100 \mu \mathrm{g}$ RNAase $\mathrm{ml}^{-1}$ at $37^{\circ} \mathrm{C}$ for $60 \mathrm{~min}$. DNA was reprecipitated as before.

Preparation of ${ }^{32} \mathrm{P}$-labelled DNA probes. Bacteriophage $\lambda$ strains were isolated as described in Maniatis $e t$ al. (1982): $\lambda$ CAl by temperature inducing an exponentially growing culture of CA148 (a bacterial strain lysogenic for the phage), $\lambda$ NK 55 by large-scale liquid culture. After degradation of cellular nucleic acids, and concentration of the phage by precipitation with polyethylene glycol (PEG 6000), phage DNA was prepared by phenol/chloroform extraction and ethanol precipitation.

Radioactive probes were prepared according to the method of Feinberg \& Vogelstein (1984). The $1.95 \mathrm{~kb} B g / \mathrm{II}$ fragment of $\lambda \mathrm{CAl}$ and $2.8 \mathrm{~kb} \mathrm{AccI}$ fragment of $\lambda \mathrm{NK} 55$ were cut out of $1 \%(\mathrm{w} / \mathrm{v})$ low-melting-point agarose gels, diluted, and used as the template for the labelling reaction. The probe was separated from unincorporated label by running it down a Sephadex G-50 column.

Southern blotting and hybridization. Chromosomal DNA was digested with appropriate restriction enzymes (buffer conditions as recommended by suppliers). Samples $(5 \mu \mathrm{g})$ were run alongside $B g / \mathrm{II}$-digested $\lambda \mathrm{CAl}$ and AccI-digested $\lambda$ NK 55 DNA on a $1.0 \%$ agarose gel in TBE electrophoresis buffer $(0.089 \mathrm{M}$-Tris/borate, $0.089 \mathrm{M}$ boric acid, 0.002 M-EDTA, pH 8.0). The gel was denatured $(0.2 \mathrm{M}-\mathrm{NaOH}, 0.6 \mathrm{M}-\mathrm{NaCl}, 30 \mathrm{~min}$ at room temperature) and washed in three changes of sodium phosphate transfer buffer $\left(0.025 \mathrm{M}-\mathrm{Na}_{2} \mathrm{HPO}_{4} / \mathrm{NaH}_{2} \mathrm{PO}_{4}\right.$, 
Table 1. Bacteria, bacteriophages and plasmids

Bacteria

\begin{tabular}{|c|}
\hline $\begin{array}{l}\text { AB1157 } \\
\text { AB1884 } \\
\text { AB1886 } \\
\text { AB2405 } \\
\text { AB2433 } \\
\text { CA148 } \\
\text { CA159 } \\
\text { CA173 } \\
\text { DM1187 } \\
\text { N3055 } \\
\text { N3124 } \\
\text { PE136 }\end{array}$ \\
\hline $\begin{array}{l}\text { Bacteriophage } \\
\text { גCA1 } \\
\lambda \text { NK } 55\end{array}$ \\
\hline $\begin{array}{l}\text { Plasmids } \\
\text { pJL26 } \\
\text { pJWF10 } \\
\text { pPE25 }\end{array}$ \\
\hline
\end{tabular}

Relevant genotype

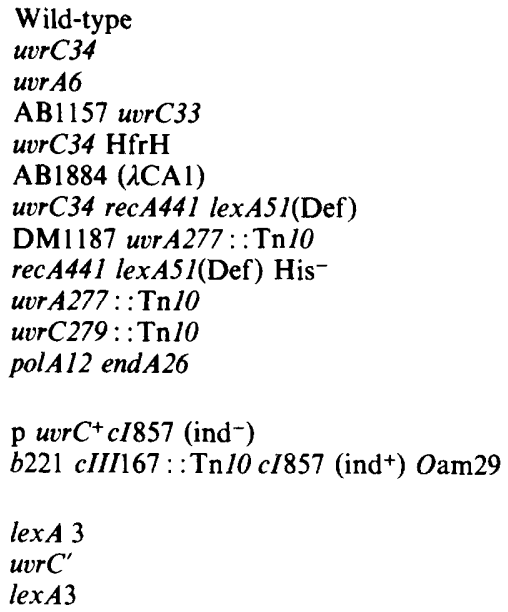

Source or reference
Our collection
Our collection
Our collection
Our collection
B. Bachmann
Lysogeny

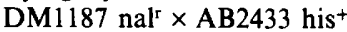
Transduction from $\mathrm{N} 3055$
Our collection
R. G. Lloyd
R. G. Lloyd
P. Emmerson
E. Seeberg
Kleckner et al. (1978a)
Little (1980)
Forster \& Strike (1984)
Emmerson et al. (1981)

pH 6.5) for $60 \mathrm{~min}$ at room temperature. DNA was transferred from the gel onto a GeneScreen hybridization membrane (New England Nuclear) using the capillary transfer method of Southern (1975). The membrane was gently washed in buffer, dried, and baked at $90^{\circ} \mathrm{C}$ for $3-4 \mathrm{~h}$.

Hybridization was done as follows. The membrane was incubated with constant agitation overnight at $60^{\circ} \mathrm{C}$ in prehybridization solution ( $5 \times$ Denhardt's solution, $250 \mu \mathrm{g}$ denatured salmon sperm DNA ml ${ }^{-1}$ ) and was transferred to hybridization solution $(1 \times$ Denhardt's solution, $0.5 \% \mathrm{SDS}, 250 \mu \mathrm{g}$ denatured salmon sperm DNA $\mathrm{ml}^{-1},<10 \mu \mathrm{g}$ denatured radioactive DNA probe $\left.\mathrm{ml}^{-1}, 0.3 \mathrm{M}-\mathrm{NaCl}, 0.002 \mathrm{M}-\mathrm{EDTA}, 0.06 \mathrm{M}-\mathrm{Tris} / \mathrm{HCl}, \mathrm{pH} 8.0\right)$ and again incubated with constant agitation overnight at $60^{\circ} \mathrm{C}$. The stock Denhardt's solution was $50 \times$ concentration and contained $1 \%(\mathrm{w} / \mathrm{v})$ BSA, $1 \%(\mathrm{w} / \mathrm{v})$ Ficoll $\left(M_{\mathrm{r}} 400000\right), 1 \%(\mathrm{w} / \mathrm{v})$ polyvinyl pyrrolidone $\left(M_{\mathrm{r}} 40000\right)$.

After hybridization, the membrane was washed twice in $0.3 \mathrm{M}-\mathrm{NaCl}, 0.002 \mathrm{M}-\mathrm{EDTA}, 0.06 \mathrm{M}-\mathrm{Tris} / \mathrm{HCl}, \mathrm{pH} \mathrm{8.0,}$ at room temperature for $5 \mathrm{~min}$, twice in the above plus $0.5 \% \mathrm{SDS}$ at $60{ }^{\circ} \mathrm{C}$ for $30 \mathrm{~min}$, and twice in $0.003 \mathrm{M}$-Tris base at room temperature for $30 \mathrm{~min}$. The membrane was not allowed to dry before autoradiography; subsequently the probe was stripped from the membrane by washing in $0.5 \mathrm{M}-\mathrm{KOH}$ at room temperature for $60 \mathrm{~min}$. The removal of all radioactive probe was confirmed by autoradiography.

\section{RESULTS AND DISCUSSION}

\section{SOS dependence of incision in uvrC34 mutants}

We have compared the extent of post-irradiation incision observed in uvrC 34 cells in both the presence and the absence of the transcription-inhibiting drug rifampicin (Fig. 1). Incision is reduced by the drug to similar levels to those observed in a uvr $A$ mutant. The simplest explanation is that incision in $u v r C 34$ mutants requires the induction of damage-inducible genes, and that the amounts of the gene products present in uninduced cells are insufficient to allow readily detectable levels of incision when induction is prevented by rifampicin. Similar experiments (results not shown) were done using chloramphenicol, which has its effects at the translational level. A slight decrease in strand incision was observed, but the effect was not as great as that with rifampicin. It has previously been observed that rifampicin is particularly effective in repressing the induction of the recA gene product by DNA damage (Satta et al., 1979).

In an attempt to confirm the SOS dependence of incision in $u v r C$ mutants, a rec $A 56$ mutation, which prevents induction of the SOS regulon, was introduced into a uvrC34 mutant; it appears that incision in the $u v r C 34$ rec $A 56$ strain (not shown) is only slightly reduced from the levels observed in the $u v r C 34$ single mutant. However, the absence of a functional RecA protein makes 




Fig. 1

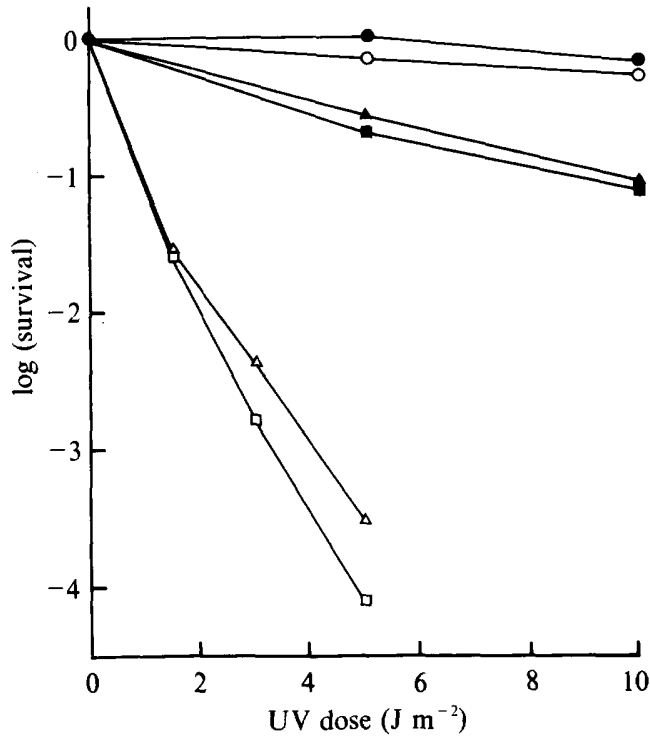

Fig. 2

Fig. 1. Formation of single-stranded breaks in E. coli DNA following UV irradiation. PE136 (uvr ${ }^{+}$polA12 endA26); $\triangle$, AB1884 (uvrC34); $\triangle$, CA159 (uvrC34 recA441 lexA5l); O, AB1884 + rifampicin $\left(200 \mu \mathrm{g} \mathrm{ml}^{-1}\right) ; \square, \mathrm{AB} 1884+$ pPE25 (lexA3); $\nabla, \mathrm{AB} 1886$ (uvrA6); $\boldsymbol{\nabla}, \mathrm{CA} 173$ (uvrA277 : :Tn10 recA441 lexA51). $\mathrm{M}_{\mathrm{n}}$, average mass number.

Fig. 2. Complementation of UV-repair defects in E. coli. , AB1157 (uvr $\left.{ }^{+}\right) ; \triangle, \mathrm{AB} 1884(u v r C 34) ; \mathbf{\Delta}$,

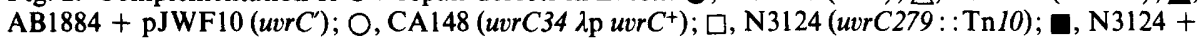
pJWF10.

the double mutant deficient in not only excision repair but also recombination repair (Rupp et al., 1971). This deficiency would lead to the production at replication forks of single-stranded gaps, which are indistinguishable by this method from single-stranded nicks. Similarly, the addition of a $\operatorname{rec} B$ mutation to a $u v r C 34$ mutant leads to only a modest reduction in incision; the rec $B$ mutation has been shown to have little effect on the efficiency with which the rec $A$ gene product is induced by UV irradiation (Little \& Hanawalt, 1977).

A different approach to repressing the SOS system involved introducing a multicopy plasmid carrying the mutant lexA3 gene into the $u v r C$ strain. The presence of such plasmids in bacterial cells has been shown to sensitize them to UV irradiation by effectively switching off the cells' SOS response, the mutated LexA protein being resistant to the cleavage activity of the RecA protein (Little et al., 1981). The effect of introducing the plasmid pPE25 into AB1884 (uvrC34) was to markedly reduce the amount of observed strand breakage. In contrast, the presence of the plasmid had little effect on incision in AB1886 (uvr A6, not shown). Similar results were obtained using pJL26, which also encodes the uncleavable LexA3 protein. It proved impossible to assess the effect of these plasmids on $u v r^{+}$cells, since in order to effectively detect incisions in such strains, rapid completion of excision repair must be blocked by a mutation in either of the genes polA or lig. pPE25 and pJL26 are both based on the ColE1 replicon, and therefore have an absolute requirement for DNA polymerase I for their replication (Cooper \& Hanawalt, 1972). They proved to be unstable in polA12 strains, even at $30^{\circ} \mathrm{C}$, and were also rapidly lost from lig-7(Ts) strains.

As a further way of investigating the SOS dependence of incision, the lexA51 (spr) mutation was introduced into a uvrC34 strain. This mutation inactivates the LexA protein (Pacelli et al., 
1979) and thus allows constitutive expression of those functions which it normally represses. If incision capacity were normally induced by DNA damage in $u v r C$ mutants, the introduction of such a mutation would be expected to alter the kinetics of incision, with the breaks being introduced much more rapidly. Fig. 1 shows this to be the case; the speed with which strand breaks are produced is very much greater in the double mutant than in the $u v r C$ strain (an effect which is reversed by the introduction into the strain of pJL26, not shown). Indeed, most of the breaks are made within the first $5 \mathrm{~min}$ after irradiation, exactly as in $u v r^{+}$strains. However, the extent of incision is still limited compared to wild-type strains, and does not exceed the level normally seen in $u v r C$ cells after prolonged incubation. In these respects, the behaviour of the uvrC34 lexA51 strain is very similar to that of a uvrC34 lig-7(Ts) strain, provided the latter has been incubated at the non-permissive temperature for at least $60 \mathrm{~min}$ (Seeberg \& Rupp, 1975). This similarity might well be a reflection of the effective induction of SOS functions by ligase inactivation (Morse \& Pauling, 1975). In contrast, a uvrA6 lexA51 double mutant, when compared with the uvrA single mutant, showed little difference in either the extent or the kinetics of incision.

Preventing the expression of damage-inducible genes after irradiation slows or prevents the formation of single-stranded breaks in uvrC34 mutants. Conversely, prior expression of SOS genes leads to an increase in the rate of incision. In all cases, altering the expression of SOS functions also alters post-irradiation incision in $u v r C 34$ strains, but has little or no effect on incision in $u v r A$ mutants. These data support the hypothesis that an SOS-inducible gene is a ratelimiting factor in incision in uvrC34 mutants. Early results suggested that uvrC might be damage-inducible (van Sluis et al., 1983), but later work has shown this not to be the case (Forster \& Strike, 1985, Granger-Schnaar et al., 1986, Moolenaar et al., 1987). The noninducibility of $u v r C$ implies that the inducible component must be either UvrA and UvrB proteins, or some other gene product able to substitute for UvrC but which still interacts with UvrA (a uvrA uvrC double mutant shows no incision, data not shown).

One possible explanation might be that the uvrC34 mutation is 'leaky', and that increasing the availability of UvrA and UvrB proteins allows the defective protein to produce a limited number of aberrant incisions more rapidly. Turning off the expression of SOS genes would have the opposite effect.

\section{Characterization of a transposon insertion in uvrC}

Strain N3124 is a derivative of AB1157 constructed by P1-mediated transduction from strain N3024 of the Tn10-encoded tetracycline-resistance marker. N3024 was selected as a mitomycin$\mathrm{C}$-sensitive, UV-sensitive, host-cell-reactivation-deficient derivative of $\mathrm{W} 3110$, produced by Tn10 mutagenesis according to the method of Kleckner et al. (1978a), namely infection with $\lambda$ NK55 and selection for tetracycline resistance (R. G. Lloyd, personal communication).

$\mathrm{N} 3124$ is also highly sensitive to UV irradiation (Fig. 2) and mitomycin C. UV sensitivity is partially complemented by pJWF10 (a high-copy-number plasmid encoding a slightly truncated uvrC gene product: Forster \& Strike, 1985), and is completely complemented by a lysogenic $\lambda C A 1$ (a derivative of $\lambda$ puvr $C^{+}$constructed by in vivo recombination with $\lambda$ cI857: Blingsmo et al., 1981; E. Seeberg, personal communication). It is also approximately $100 \%$ cotransducible (by T4gt7, Wilson et al., 1979) with tetracycline resistance (the cotransducibility can only be estimated, since some or all of any $\mathrm{Tet}^{\mathrm{r}} \mathrm{UV}^{\mathrm{r}}$ colonies may be a consequence of transposition of the Tn10 element). These data strongly suggest that the UV sensitivity of N3124 is due to a Tn10-associated $u v r C$ mutation, and that it carries no additional copies of $\operatorname{Tn} 10$.

To further characterize the putative mutation in $u v r C$ carried by $\mathrm{N} 3124,{ }^{32} \mathrm{P}$-labelled $u v r C$ DNA was used to probe Southern blots of chromosomal DNA from AB1157 and N3124, digested with a variety of restriction enzymes. In this way, any changes in the $u v r C$ region of the chromosome could be assessed. Preliminary results (not shown) using a heterogeneous probe (isolated from a $H$ indIII/EcoRI digest of $\lambda C A 1$ DNA) showed the $u v r C$ region to be disrupted in $\mathrm{N} 3124$, and suggested that this was due to a Tn 10 insertion directly into the $u v r C$ structural gene.

Tn 10 has been restriction mapped (Kleckner et al., 1978b; our unpublished data) and the right-hand half has been sequenced (Halling et al., 1982, Hillen \& Schollmeier, 1983; N. 




Fig. 3. Restriction analysis of the $u v r C$ region of strain N3124 chromosomal DNA by Southern blotting, probed with (a) uvrC $C^{+}$DNA or (b) Tn 10 DNA (see main text). 1, $\lambda \mathrm{CAl} B g l \mathrm{II} ; 2, \mathrm{AB} 1157 \mathrm{Bg} / \mathrm{II}$; 3, ABl157 Pstl/HindIII; 4, AB1157 PstI/HindIII/EcoRI; 5, N3124 BglII; 6, N3124 HindIII/EcoRI; 7, N3124 HindIII/EcoRI/PstI; 8, גNK55 AccI.

Kleckner, personal communication). This enabled enzymes to be chosen which would facilitate accurate determination of the position of the presumed insertion. The procedure was repeated, this time using a probe isolated from a $B g l$ II digest of $\lambda C A 1$ DNA (Fig. $3 a$ ). It is immediately apparent that the $1.95 \mathrm{~kb} \mathrm{BglII}$ fragment carrying the $u v r C$ gene (track 2) has been rearranged in N3124 to give two fragments hybridizing to uvrC DNA, 3.55 and $4.75 \mathrm{~kb}$ in length (track 5); similarly, a comparison of tracks 3 and 7 also shows rearrangement of $u v r C$. In each case, the change in fragment length is fully in agreement with that expected from an insertion of Tn 10. The position and orientation of this insertion into the $u v r C$ gene can be unambiguously determined from the sequence and restriction data; $350 \pm 20$ bp upstream from the $3^{\prime}$ BglII site, with IS 10 -R on the $5^{\prime}$ side (Fig. 4).

The only simple alternative to an insertion directly into the $u v r C$ gene is a chromosomal rearrangement associated with an insertion of $\mathrm{Tn} 10$ nearby - Tn 10 readily generates deletions and inversions of neighbouring chromosomal material, with one endpoint at or within the Tn 10 element itself (Kleckner et al., 1979). To be consistent with the data from track 5, a Tn10associated chromosomal inversion would have to start from a point between the two $B g l$ II sites, and extend upstream beyond the PstI sites, or downstream beyond the EcoRI site. No such inversion can be reconciled with the data from both of tracks 6 and 7 , suggesting that $u v r C$ has not been subjected to a significant chromosomal rearrangement.

To confirm that the rearrangement of $u v r C$ was due to the addition of $\mathrm{Tn} 10$ material, the nylon membrane was stripped of $u v r C$ probe, using $0.5 \mathrm{M}-\mathrm{KOH}$, and was reprobed with the $2.8 \mathrm{~kb} A c c \mathrm{I}$ 
(a)


(b)

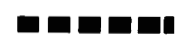

Fig. 4. Restriction maps of the $u v r C$ region of the $E$. coli chromosome, and of transposon Tn 10 , showing the site of insertion of $\mathrm{Tn} / 0$ in strain N3124. The two solid bars indicate the DNA fragments used as probes in Fig. 3(a) and (b), respectively. The broken bar indicates a region homologous to part of the probe used in Fig. $3(b)$.

fragment of Tn10 DNA indicated in Fig. 4. The AB1157 tracks showed no sequences homologous to the Tn 10 probe (Fig. 3 b). In contrast, the N3124 tracks showed the same bands as in Fig. 3(a), plus additional bands corresponding in size to fragments internal to $\operatorname{Tn} 10$. The exact correspondence of restriction fragments hybridizing to $u v r C$ and Tn 10 DNA in N3124 confirms that the strain carries a $\operatorname{Tn} 10$ insertion mutation of $u v r C$.

\section{Post-irradiation incision in a uvrC null mutant}

It has been suggested that the carboxy-terminus of UvrC protein is important in excision repair (Sharma et al., 1986), a hypothesis consistent with the incomplete complementation by pJWF10 of $u v r C$ defects (Fig. 2). The insertion mutation in N3124 is likely to result in a UvrC protein truncated by approximately 100 amino acid residues at its carboxy-terminus, so it might be expected that $\mathrm{N} 3124$ encodes a $u v r C$ gene product which has lost most, if not all, of its function, at least with respect to excision repair - a uvrC null mutant.

Post-irradiation incision in N3124 was assessed, and compared with that in AB1884 (uvrC34). Fig. 5 shows that single-stranded break formation was reduced to levels comparable to those seen in uvrA mutants. A uvrA:: $\operatorname{Tn} 10$ mutant, $\mathrm{N} 3055$, showed little difference in incision capability from a $u v r A 6$ mutant. The implication is that complete loss of $u v r C$ function is accompanied by complete loss of incision capability, the formation of single-stranded breaks in uvrC34 mutants being due to an altered UvrC protein; i.e. uvrC34 is 'leaky', at least with respect to post-irradiation incision. A comparison of the UV sensitivities of N3124 and AB1884 shows the uvrC34 mutant to be more UV resistant by a small but significant amount, again suggesting that it is a 'leaky' mutation. The variable levels of incision observed in various other uvrC mutants suggest that such mutations are also incomplete: uvrC56 (Sharma \& Moses, 1979; Tang \& Ross, 1985) and uvrC33 (Fig. 5) have similar incision kinetics to uvrC34, but the extent of incision varies, uvrC33 leading to a markedly greater level of single-stranded breaks.

The events leading to incision in vitro are now well understood. UvrA protein binds to DNA in an ATP-dependent, damage-dependent manner (Seeberg \& Steinum, 1982); UvrB stabilizes such an association, binding to form a stable complex (Kacinski \& Rupp, 1981; Strike \& Rupp, 1985); finally, UvrC completes the excinuclease, resulting in incision in vitro (Young et al., 


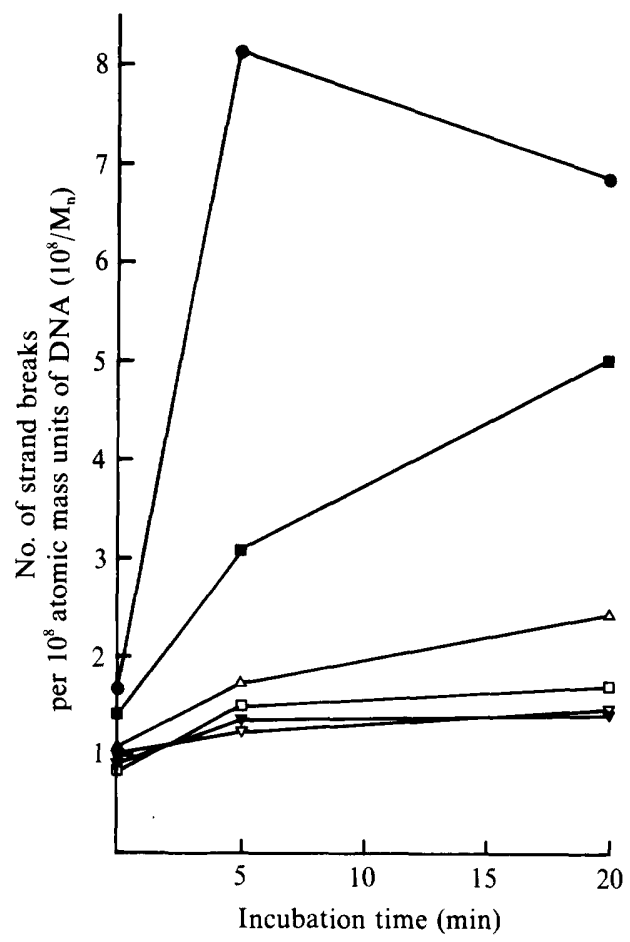

Fig. 5. Effect of $u v r C$ alleles on post-irradiation incision in E. coli. $\bigcirc$, PE136 (uvr ${ }^{+}$polA12 endA26); $\triangle$, $\mathrm{AB} 1884$ (uvrC34); $\square, \mathrm{N} 3124$ (uvrC279::Tn10);, $\mathrm{AB} 2405$ (uvrC33); $\nabla, \mathrm{AB} 1886$ (uvrA6); $\nabla, \mathrm{N} 3055$ (uvrA277: : $\operatorname{Tn} 10$ ). $\mathrm{M}_{\mathrm{n}}$, average mass number.

1986). The above data suggest that the same is true in vivo. The UvrABC complex remains tightly bound following incision, requiring the combined action of helicase II and DNA polymerase I to be released (Husain et al., 1985; Caron et al., 1985). In an SOS-induced cell, UvrA and UvrB proteins are present in vast excess over the low level of UvrC (Yoakum \& Grossman, 1981). A defect at any stage following incision which prevents UvrC turnover would result in the rapid depletion of UvrC. As a consequence there would be a low level of incision rapidly reaching a plateau, exactly as observed in vivo in $u v r C$ mutants. The defect in repair in a uvrC34 mutant might be either in incision leading to a block in turnover, or in turnover itself.

The unusual phenotype of $u v r C 34$ mutants, compared with $u v r A$ and $u v r B$ mutants, extends to the repair of chemically damaged transforming plasmids. $N$-2-Aminofluorene (AF) adducts are removed in vitro by the UvrABC excinuclease and yet are readily tolerated by both $u v r^{+}$and $u v r A$ strains (Fuchs \& Seeberg, 1984); uvrC34 mutants, however, are sensitive to AF lesions, although this is suppressed by an additional $u v r A$ mutation. Bichara \& Fuchs (1987) suggest the sensitivity of uvrC34 strains is due to impaired or defective UvrABC function, a conclusion supported by the sensitivity of $u v r D$ cells. These effects are consistent with a $u v r C 34$ mutation causing a block in UvrABC turnover, which in turn would block replication of the plasmid, leading to plasmid loss.

The effects of uvr mutations on resident enhanced repair of UV-irradiated transforming plasmids (Strike \& Roberts, 1982) also suggests that the basis for the UV sensitivity of uvrC34 mutants lies in the block in turnover, not in incision. $u v r C 34$ and $u v r D$ mutations have no effect on resident enhanced repair, while $u v r A$ and $u v r B$ mutations completely eliminate repair, resident-enhanced or otherwise (Roberts \& Strike, 1981). The incompatible resident plasmid seems to provide a temporary block on replication, allowing repair to be completed (unpublished observations). As a consequence, when replication does eventually occur, the 
replication fork does not encounter any lethal lesions. In the case of a $u v r C 34$ or $u v r D$ mutant host cell, the UvrABC complex is presumably not irreversibly bound to the DNA and eventually dissociates, enabling other enzymes to complete the repair process.

The evidence shows that UvrC protein is absolutely required for the incision stage in excision repair in vivo as well as in vitro, and suggests that it may be involved in the subsequent release of the 12-13 bp single-stranded fragment containing the damage. A defective UvrC protein might be unable to turn over, resulting in a loss of incision capability, and as a consequence having toxic effects in some circumstances. Further study of the products of mutant $u v r C$ genes may be of use in the study of the enzymology of excision repair.

We thank Mrs A. C. Ritson for her excellent technical assistance, N. Kleckner for communicating results prior to their publication, and R. G. Lloyd and E. Seeberg for their gifts of bacterial and bacteriophage strains. This work was supported by an SERC studentship to R.G.W., and by an SERC grant to P.S. \& J.W.F.

\section{REFERENCES}

Bichara, M. \& Fuchs, R. P. P. (1987), uvrC gene function has no specific role in repair of $\mathrm{N}-2$ aminofluorene adducts. Journal of Bacteriology 169 , 423-426.

Blingsmo, O. L., Steinum, A. L., Rivedal, E. \& SeEberG, E. (1981). Cloning of the $\mathrm{uvrC}^{+}$gene from Escherichia coli onto a plaque-forming phage vector. In Chromosome Damage and Repair, pp. 303-309. Edited by E. Seeberg \& K. Kleppe. New York: Plenum Press.

Caron, P. R., Kushner, S. R. \& Grossman, L. (1985). Involvement of helicase II (uvrD gene product) and DNA polymerase $I$ in excision mediated by the uvr $A B C$ protein complex. Proceedings of the National Academy of Sciences of the United States of America 82, 4925-4929.

COOPER, P. K. \& Hanawalt, P. C. (1972). Role of DNA polymerase I and the rec system in excision repair in Escherichia coli. Proceedings of the National Academy of Sciences of the United States of America 69, 1156-1160.

Emmerson, P. T., Hickson, I. D., Gordon, R. L. \& Tomkinson, A. E. (1981). Cloning of $\mathrm{rec}^{+}$and lex $A^{+}$and some of their mutant alleles; an investigation of their mutual interaction. In Chromosome Damage and Repair, pp. 281-285. Edited by E. Seeberg \& K. Kleppe. New York: Plenum Press.

FeinberG, A. \& Vogelstein, B. (1984). A technique for radiolabelling DNA restriction endonuclease fragments to high specific activity. Analytical Biochemistry 137, 266-267.

Forster, J. W. \& STRIKE, P. (1985). Organisation and control of the Escherichia coli uvrC gene. Gene 35, 71 82.

Fuchs, R. P. P. \& SeEberg, E. (1984). pBR322 plasmid DNA modified with 2-acetylaminofluorene derivatives: transforming activity and in vitro strand cleavage by the Escherichia coli uvrABC endonuclease. EMBO Journal 3, 757-760.

Granger-Schnaar, M., Schnaar, M. \& van Sluis, C. A. (1985). In vitro study of the interaction of the LexA repressor and the $\mathrm{UvrC}$ protein with a $u v r C$ regulatory region. FEBS Letters 198, 61-65.

Halling, S. M., Simons, R. W., Way, J. C., Walsh, R. B. \& KLECKNER, N. (1982). DNA sequence organization of Tn10's IS10-Right and comparison with IS10-Left. Proceedings of the National Academy of Sciences of the United States of America 79, 26082612 .
Hillen, W. \& Schollmeier, K. (1983). Nucleotide sequence of the $\mathrm{Tn} 10$ encoded tetracycline resistance gene. Nucleic Acids Research 22, 525-539.

Husain, I., van Houten, B., Thomas, D. C., AbdelMOREM, M. \& SANCAR, A. (1985). Effect of DNA polymerase I and DNA helicase II on the turnover of UvrABC excision nuclease. Proceedings of the National Academy of Sciences of the United States of America 82, 6774-6778.

KACINSKI, B. M. \& RUPP, W. D. (1981). Escherichia coli $u v r B$ protein binds to DNA in the presence of the uvrA protein. Nature, London 294, 480-481.

KATO, T. (1972). Excision repair characteristics of recB $B^{-}$res $^{-}$and $u v r C^{-}$strains of Escherichia coli. Journal of Bacteriology 112, 1237-1246.

Kleckner, N., Barker, D., Ross, D. \& Botstein, D. (1978a). Properties of the translocatable tetracycline resistance element $\operatorname{Tn} 10$ in Escherichia coli and bacteriophage $\lambda$. Genetics $90,427-450$.

Kleckner, N., Swan, J. A. \& Zabeau, M. (1978b). Restriction enzyme analysis of $\mathrm{Tn} 10$ insertions in the immunity region of bacteriophage lambda. Genetics 90, 450-461.

Kleckner, N., Reichardt, K. \& Botstein, D. (1979). Inversions and deletions of the Salmonella chromosome generated by the translocatable tetracycline resistance element Tn10. Journal of Molecular Bio$\log y$ 127, 89-115.

LITTLE, J. W. (1980). Isolation of recombinant plasmids and phage carrying the lexA gene of Escherichia coli. Gene 10, 237-247.

LitTle, J. W. \& Hanawalt, P. C. (1977). Induction of protein X in Escherichia coli. Molecular and General Genetics 150, 237-248.

Little, J. W., Edmiston, S. H., Pacelli, L. Z. \& Mount, D. W. (1980). Cleavage of the Escherichia coli lexA protein by the recA protease. Proceedings of the National Academy of Sciences of the United States of America 76, 6147-6151.

Maniatis, T., Fritsch, E. F. \& Sambrook, J. (1982). Molecular cloning: a Laboratory Manual. Cold Spring Harbour, NY: Cold Spring Harbour Laboratory.

Moolenaar, G. F., van Sluts, C. A., Backendorf, C. \& VAN DE PUTTE, P. (1987). Regulation of the Escherichia coli excision repair gene $u v r C$. Overlap between the $u v r C$ structural gene and the region coding for a $24 \mathrm{kD}$ protein. Nucleic Acids Research 15, 4273-4289. 
MoRse, L. S. \& PAULING, C. (1975). Induction of errorprone repair as a consequence of DNA ligase deficiency in Escherichia coli. Proceedings of the National Academy of Sciences of the United States of America 72, 4645-4649.

Pacelli, L. Z., Edmiston, S. H. \& Mount, D. W. (1979). Isolation and characterization of amber mutations in the lexA gene of Escherichia coli K-12. Journal of Bacteriology 137, 568-573.

ROBERTS, R. J. \& STRIKe, P. (1981). Efficiency of Escherichia coli repair processes on UV-damaged transforming plasmid DNA. Plasmid 5, 213-220.

RuPP, W. D., WILDE, D. E., ReNo, D. L. \& HowardFlanders, P. (1971). Exchanges between DNA strands in UV-irradiated Escherichia coli. Journal of Molecular Biology 61, 25-44.

SANCAR, A. \& RUPP, W. D. (1983). A novel repair enzyme: UVRABC excision nuclease cuts a DNA strand on both sides of the damaged region. Cell 33, 249-260.

Satta, G., Gudas, L. J. \& Pardee, A. B. (1979). Degradation of Escherichia coli DNA: evidence for limitation in vivo by protein $\mathrm{X}$, the rec $A$ gene product. Molecular and General Genetics 168, 69-80.

SEeberG, E. \& RUPP, W. D. (1975). Effects of mutations in lig and polA on UV-induced strand cutting in a uvrC mutant of Escherichia coli. In Molecular Mechanisms in DNA Repair, pp. 439-441. Edited by P. C. Hanawalt \& R. B. Setlow. New York: Plenum Press.

Seeberg, E. \& Steinum, A. L. (1982). Purification and properties of the uvrA protein from Escherichia coli. Proceedings of the National Academy of Sciences of the United States of America 79, 988-992.

SeEberg, E. \& STRIKe, P. (1976). Excision repair of ultraviolet-irradiated deoxyribonucleic acid in plasmolysed cells of Escherichia coli. Journal of Bacteriology 125, 787-795.

Seeberg, E., Nissen-Meyer, J. \& Strike, P. (1976). Incision of ultraviolet-irradiated DNA by extracts of Escherichia coli requires three different gene products. Nature, London 263, 524-526.
Seeberg, E., Rupp, W. D. \& Strike, P. (1980). Impaired incision of ultraviolet-irradiated deoxyribonucleic acid in uvrC mutants of Escherichia coli. Journal of Bacteriology 144, 97-104.

SHARMA, S. \& MOSES, R. E. (1979). uvrC gene function in excision repair in toluene-treated Escherichia coli. Journal of Bacteriology 137, 397-408.

Sharma, S., Stark, T. F., Beattie, W. G. \& Moses, R. E. (1986). Multiple control elements for the uvrC gene unit of Escherichia coli. Nucleic Acids Research 14, 2301-2318.

van Sluis, C. A., Moolenaar, G. F. \& Backendorf, C. (1983). Regulation of the uvrC gene of Escherichia coli K12: localization and characterization of a damage-inducible promoter. The EMBO Journal 2, 2313-2318.

SOUTHERN, E. (1975). Detection of specific sequences among DNA fragments separated by gel electrophoresis. Journal of Molecular Biology 98, 503-517.

STRIKE, P. \& RoBERTS, R. J. (1982). Resident enhanced repair: novel repair process action on plasmid DNA transformed into Escherichia coli K-12. Journal of Bacteriology 150, 385-388.

STRIKE, P. \& RUPP, W. D. (1985). Cross-linking studies with the uvrA and $u v r B$ proteins of Escherichia coli. Mutation Research 145, 43-48.

TANG, M. S. \& Ross, L. (1985). Single-strand breakage of DNA in UV-irradiated $u v r A, u v r B$, and $u v r C$ mutants of Escherichia coli. Journal of Bacteriology 161, 933-938.

Wilson, G. G., Young, K. K. Y., Eduin, G. J. \& KONIGSBERG, W. (1979). High frequency generalised transduction by bacteriophage T4. Nature, London 280, 80-82.

Yeung, A. T., Mattes, W. B. \& Grossman, L. (1986). Protein complexes formed during the incision reaction catalysed by the Escherichia coli UvrABC endonuclease. Nucleic Acids Research 14, 2567-2582.

YoAKUM, G. H. \& Grossman, L. (1981). Identification of the uvrC protein. Nature, London 292, 171-173. 